\title{
PAPER
}

\section{Helicobacter and gastric MALT lymphoma}

\section{Stolte, E Bayerdörffer, A Morgner, B Alpen, T Wündisch, C Thiede, A Neubauer}

Gut 2002;50(Suppl III):iii 19-iii24

Helicobacter pylori infection is a pre-MALT lymphoma condition. $\mathrm{H}$ pylori eradication leads to complete remission in $80 \%$ of low grade stage E 1 lymphomas, with a yearly recurrence rate of approximately $5 \%$. The possibility for complete remission in high grade lymphomas needs to be investigated in prospective studies. In addition, the significance of persistent B cell monoclonality (stable disease? danger of relapse? regression of monoclonality?) needs to be investigated in follow up studies.

See end of article for authors' affiliations

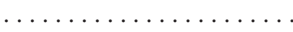

Correspondence to: Prof. Dr M Stolte, Institut für Pathologie, Klinikum Bayreuth, Preuschwitzer Str. 101, D-95445 Bayreuth, Germany; pathologie.klinikum@bnbt.de
$\mathrm{P}$ resumably no other area of gastroenterology has seen such great advances over the past 20 years as that of malignant lymphomas of the stomach. These advances may be summarised as follows:

- Lymphomas are today being detected much more frequently at an early stage

- In addition to high grade lymphomas, low grade lymphomas are increasingly being diagnosed

- A new, improved histological classification of these lymphomas has been developed

- Considerable advances have been made in our understanding of the pathogenesis of lymphoma.

The biggest breakthrough was achieved by research into the relation between Helicobacter pylori infection of the stomach and gastric lymphoma, which has shown that:

- Mucosa associated lymphoid tissue (MALT) of the stomach is always a sequela of $H$ pylori infection

- Acquired MALT is the precondition for the potential development of a MALT lymphoma

- In more than $90 \%$ of cases, MALT lymphoma is associated with $H$ pylori infection

- Prior $H$ pylori infection is therefore a pre-MALT lymphoma condition

- In animal experiments MALT lymphomas can be induced by H pylori infection

- H pylori eradication alone can lead to complete remission of the MALT lymphoma.

However, numerous questions have still to be answered:

- What additional factors are needed to transform a reactive lymphocytic proliferation into a MALT lymphoma?

- Why do some low grade lymphomas regress after $H$ pylori eradication, while other do not?
- What $H$ pylori or $\mathrm{T}$ lymphocyte products influence the proliferation of lymphoma cells, and via what receptors on the tumour cells?

- Is complete remission after $H$ pylori eradication lasting, and how high is the local recurrence rate?

- Are there antigen responsive tumours other than the MALT lymphomas of the stomach?

\section{THE SITUATION PRIOR TO THE AGE OF H PYLORI}

Until the beginning of the 1980s, gastric lymphoma was categorised in accordance with the endoscopic classification suggested by Palmer in 1950. ${ }^{1}$ At that time the lymphomas the pathologists were able to examine were, for the most part, large advanced tumours, with infiltration of all layers of the gastric wall, infiltration of neighbouring tissue, and involvement of the regional lymph nodes.

The lymphomas found in biopsy material were frequently wrongly diagnosed as carcinomas, and for further diagnostic work up gastric resection was often recommended. The histological classification was, simply and undifferentiatedly, "lymphosarcoma".

Three milestones in 1983 and 1984 heralded the end of this unsatisfactory state, and the beginning of a positive development. Isaacson and Wright developed the MALT concept of gastric lymphoma, ${ }^{2}$ Warren and Marshall described $\mathrm{H}$ pylori, ${ }^{3}$ and from Japan came-in analogy to early carcinomas- the first reports on early gastric lymphomas with limitation of the infiltration to the mucosa and submucosa. ${ }^{4}$ In the following years the percentage of early lymphomas among gastric lymphomas increased rapidly. The figure for material from Vienna covering the period 1974-78 was $21.7 \%,{ }^{5}$ in Tokyo between 1977 and 1986, 40.9\%, ${ }^{6}$ and in our own material between 1983 and 1989, 49.6\%.

At the time of their diagnosis, early lymphomas of the stomach already have a relatively large diameter, not different from that of advanced lymphomas. ${ }^{7}$ They can be recognised macroscopically by a number of coincident findingsthickened folds, erosions, and ulceration. ${ }^{28}$ As in early gastric carcinomas, these lesions undergo a malignant cycle, ${ }^{9}$ healing and reappearing again, with the result that a variegated picture including thickened folds, erosions, ulcers, scars, and regenerative mucosa is seen.

The fact that early lymphomas already have a relatively large diameter-on average approximately $8 \mathrm{~cm}$-when diagnosed, could have

Abbreviations: MALT, mucosa associated lymphatic tissue; PCR, polymerase chain reaction 


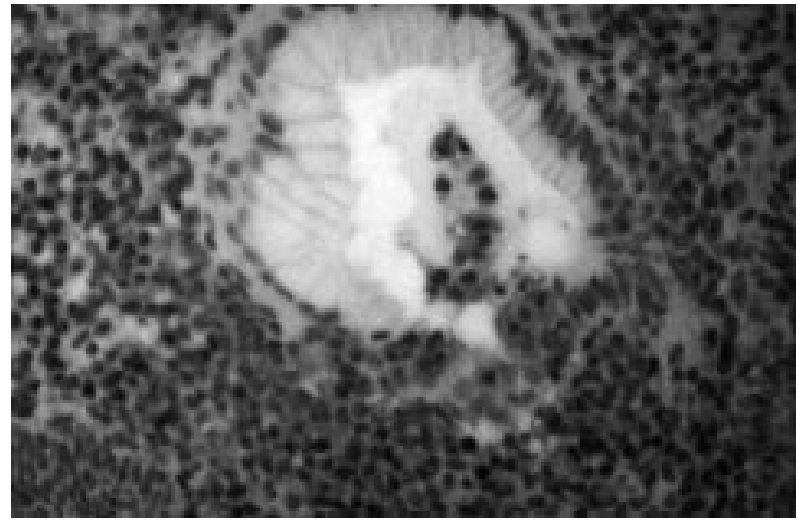

Figure 1 Partial destruction of a gastric gland by infiltrates of a low grade MALT lymphoma (immunohistochemistry with CD 20 antibody).

prompted us to suspect that there must be a growth stimulating factor on the surface of the mucosa.

Recognition of the early lymphoma was a step forward, as shown by the following data: the depth of infiltration correlates with the involvement of the regional lymph nodes and with the degree of malignancy of the tumour ${ }^{10}$; the deeper the infiltration, the greater the number with lymph node involvement, and the more cases with high grade malignancy. The fact that depth of infiltration is the major prognostic factor in cases with gastric lymphoma is therefore logical. ${ }^{1}$

Advances in the early endoscopic-bioptic diagnosis is also reflected in the change in the relative proportions of low grade and high grade lymphomas. While, formerly, a preponderance of the lymphomas diagnosed were high grade, ${ }^{12}$ in the 1990 s a higher percentage of low grade lymphomas were detectedthe percentage of low grade lymphomas in our material from 351 patients in the period $1993-98$ was $77.2 \%$.

At the end of the 1980s the first good histological classification was proposed by Isaacson and colleagues. ${ }^{13}$ Because the site of the tumour origin is the perifollicular marginal cell, in the revised European-American classification of lymphoid neoplasms ${ }^{14}$ and the new WHO classification of tumours of the digestive system, ${ }^{15}$ the lymphoma is also termed a marginal $\mathrm{B}$ cell lymphoma. Primary $\mathrm{T}$ cell lymphomas of the stomach are very rare. Among our 220 surgical specimens with gastric lymphoms, only two were T cell lymphomas. ${ }^{10}$

The decisive advance in biopsy based diagnosis of low grade malignant gastric lymphomas was the establishment of the following histological criteria by Isaacson and colleagues ${ }^{16}{ }^{17}$ :

(1) Replacement of gastric glands by uniform infiltrates comprising centrocytoid cells (see fig 3)

(2) Clear evidence of lymphoid destruction of gastric glands of foveolae (figs 1 and 2).

The diagnosis of gastric low grade MALT lymphoma should be made only when invasive and destructive tumour growth is proven. That is, when foveolae and/or glands are partially or almost completly destroyed by the lymphoid cells.

For an accurate histological diagnosis of a gastric MALT lymphoma, the first diagnostic work up often needs to be followed by a problem oriented endoscopic-bioptic investigation with the additional aim of detecting possible focal transformation to high grade lymphoma. For such an investigation, at least 15 biopsy specimens should be obtained from any endoscopically suspicious lesion. ${ }^{18}$

\section{DISCOVERY OF THE RELATION BETWEEN H PYLORI, MALT, AND MALT LYMPHOMAS}

The paths of $H$ pylori and gastric MALT lymphoma research crossed for the first time in 1988 with the recognition that the

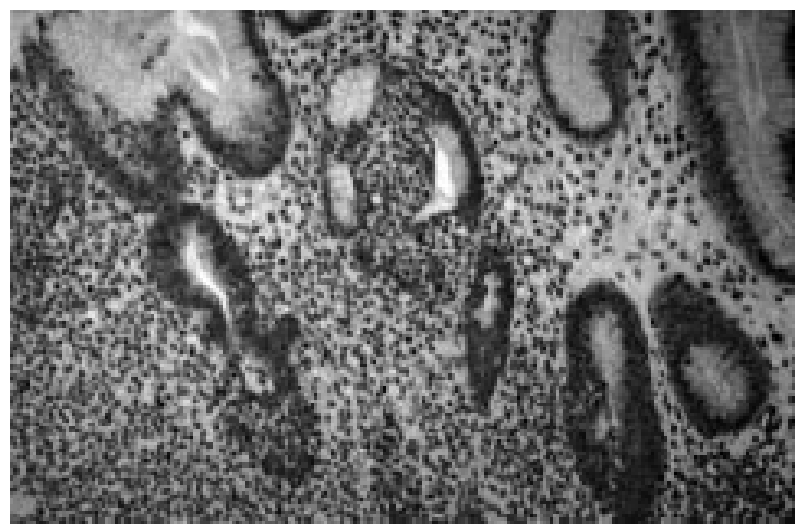

Figure 2 Multiple lymphoepithelia lesions in a low grade MALT lymphoma (immunohistochemistry with a pancytokeratin antibody).

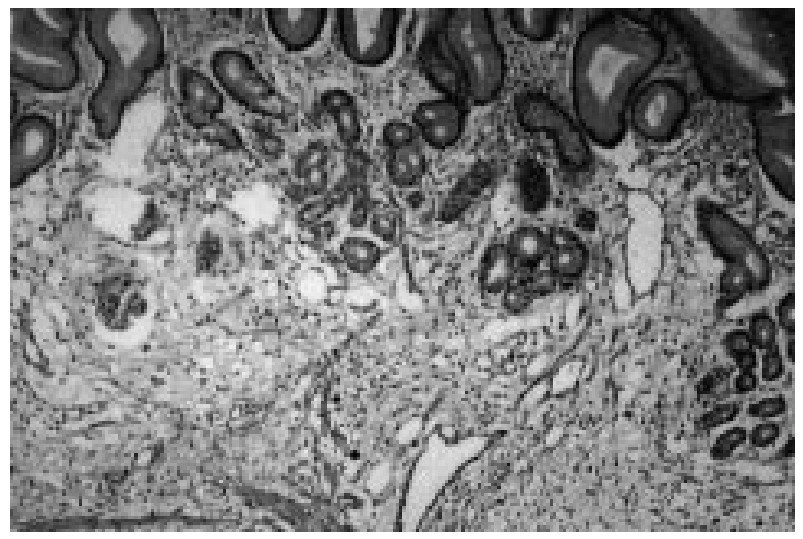

Figure 3 Complete remission of a low grade MALT lymphoma after $\mathrm{H}$ pylori eradication with the typical picture of an empty lamina propria.

cause of acquired gastric MALT is chronic infection with $H$ pylori. ${ }^{19}{ }^{20}$ The first piece of the puzzle that helped clarify this relation was an epidemiological study which showed the dependence of the incidence of MALT lymphoma on the $H$ pylori infection rate. ${ }^{21}$ The second was the fact that the early lymphomas-like acquired MALT-are located mainly in the gastric antrum. ${ }^{7}$

Analysis of surgical specimens of gastric MALT lymphoma showed $H$ pylori gastritis in $92.0-98.3 \% .^{1022}$ Furthermore the case-control study performed by Parsonnet and colleagues ${ }^{23}$ showed a statistically significantly higher $H$ pylori infection rate among MALT lymphoma patients long before development of the lymphoma. This is proof of the fact that $H$ pylori gastritis is a pre-MALT lymphoma condition. Finally, animal experiments showed that lifelong infection of mice with $H$ felis led to the development of gastric MALT lymphomas in $26 \%$ of cases. ${ }^{24} 25$ In a further study, the group of Adrian Lee transplanted gastric lymphoma cells subcutaneously or intraperitoneally in young mice. Only those animals infected with $H$ pylori developed lymphomas; control animals with no $H$ pylori infection did not. However, the lymphomas were not located at the sites of the subcutaneous or intraperitoneal transplantation, but in the stomach of the animals. ${ }^{26}$ Over a long follow up period, some of these lymphomas underwent transformation from low grade to high grade lymphomas. ${ }^{27}$

In contrast, in another strain of mice, lifelong infection with $H$ felis led to a severe form of gastritis with atrophy, but no lymphomas. Experimental gastric lymphoma induction in $\mathrm{BALB} / \mathrm{C}$ mice is also possible using $H$ heilmannii, but the rates differ-from $14 \%$ to $89 \%$, depending on the host of the infection. ${ }^{28}$ 
These animal experiments suggest that the factors necessary to induce development of a gastric lymphoma in acquired MALT are probably to be sought among different bacterial and host factors.

In this context it is of interest to note that patients with $H$ heilmannii gastritis apparently develop a MALT lymphoma more frequently than those with $H$ pylori gastritis: in our material from 1988 to 1998, eight MALT lymphomas among 543 patients with $H$ heilmannii gastritis (1.47\%) compared with 1745 MALT lymphomas among 263680 patients with $H$ pylori gastritis $(0.66 \%)$. As with the BALB/C mice in the animal experiments performed by the group headed by Adrian Lee, $H$ heilmannii gastritis was lower grade and less active than $H$ pylori gastritis. ${ }^{29}$ In support of this association with a milder form of gastritis is the fact that a matched control study of all material showed that, in patients with gastric MALT lymphoma, gastritis is of lower grade in comparison with other $H$ pylori induced diseases, and there is no difference between the gastric score in the antrum and corpus. ${ }^{30}$

With regard to $H$ heilmannii infection of the gastric mucosa, further studies have since shown that several types of $H$ heilmannii exist, which can be transmitted by various domestic animals (dogs, cats, pigs) and may also present as a mixed infection of the gastric mucosa. ${ }^{31}$

It is thus possible that special antigens, arising directly from those strains of Helicobacter that are weakly pathogenic, or indirectly via $\mathrm{T}$ lymphocytes, result in a positive selection of tumour cells via the antigen receptor. This is supported by a study showing that MALT type lymphoma B cells are hypermutated postgerminal centre lymphocytes that have undergone antigen selection. ${ }^{32}$ Furthermore, it has been reported that changes to the $\mathrm{p} 53$ suppressor gene are involved in the development and transformation of MALT lymphomas; partial inactivation leads to the development of low grade MALT lymphomas, and complete inactivation to high grade MALT lymphomas. ${ }^{33}$

Molecular-genetic studies of MALT lymphoma of the stomach presently available do not yet reveal the whole picture, and further work is needed. The stepwise acquisition of genetic abnormalities can be divided into early and later molecular events. Early molecular events in the evolution of gastric MALT lymphoma include trisomy 3 (33\% of gastric MALT lymphomas), but this event does not seem to play a major role in progression. ${ }^{34}$ The $\mathrm{t}(1 \mathrm{l} ; 18)(\mathrm{q} 2 \mathrm{l} ; \mathrm{q} 21)$ chromosome translocation is also an early, frequent, and specific aberration in low grade MALT lymphomas. ${ }^{35-37}$ This translocation seems to be absent in high grade gastric lymphomas, which suggests that low grade MALT lymphomas that are positive for the $\mathrm{t}(11 ; 18)(\mathrm{q} 21 ; 21)$ translocation may represent a subgroup for progression to advanced lymphoma. Another molecular event in the early phase of lymphomagenesis is $\mathrm{Bcl}-2$ protein overexpression. Therefore, inhibition of apoptosis seems to be involved in lymphomagenesis. ${ }^{38}$ Expression of p53 protein is inversely correlated to Bcl-2 expression, and it is more common in high grade gastric lymphomas. Therefore, mutations of the p 53 gene may be related to histological transformation of low to high grade lymphoma. ${ }^{38-40}$

\section{H PYLORI ERADICATION AND MALT LYMPHOMA}

The discovery of complete remission of the low grade MALT lymphoma was initiated by attempts to improve the endoscopic-bioptic differential diagnosis between reactive lymphatic infiltrates and low grade MALT lymphoma infiltrates. We advanced the hypothesis that reactive lymphatic infiltrates should disappear, but lymphoma infiltrates persist, in response to $H$ pylori eradication. ${ }^{4}$

To our great surprise our first analysis of 32 patients studied in 1992 showed that the MALT lymphomas could also disappear: in six out of 10 patients with low grade MALT lymphomas follow up revealed regression of lymphoma. Two of these six patients were submitted to gastric resection; in both cases we found an empty lamina propria with small remnants of aggregates of $\mathrm{T}$ lymphocytes, indicating regression of the tumour-a picture once seen only after successful chemotherapy or radiotherapy of gastric MALT lymphomas (see fig 3).

In 1993 Wotherspoon and colleagues ${ }^{42}$ reported regression of low grade gastric MALT lymphomas in five out of six patients. The same group investigated the proliferation behaviour of tumour cells from low grade and high grade MALT lymphomas in cell cultures with and without $H$ pylori, and with and without T lymphocytes. It was found that the cells of the low grade MALT lymphomas proliferate only when the culture medium contains both $H$ pylori and T lymphocytes, but not when either $H$ pylori or T lymphocytes are absent. In contrast, proliferation of high grade lymphoma cells was not influenced by the absence of $H$ pylori or T lymphocytes. ${ }^{43}$

\section{German MALT lymphoma study}

Encouraged by these initial results we began to study the treatment of low grade gastric MALT lymphomas consisting solely of eradication of $\mathrm{H}$ pylori. We have already published a number of reports on initial results, and also the results of follow up examinations. ${ }^{44-46}$ We concluded this study after we had entered 120 patients, who still remain under surveillance.

We admitted only patients with a histologically unequivocal diagnosis of MALT lymphoma. We also complied with the recommendation of Isaacson and Norton that MALT lymphoma should be diagnosed only when the endoscopic findings are compatible with MALT lymphoma. ${ }^{47}$ Endoscopy and biopsy follow up examinations were performed after $H$ pylori eradication, initially at intervals of two months and then, after achieving complete remission, at intervals of six months. In patients with partial remission and in those showing no change to tumours, surgical treatment, radiotherapy, or chemotherapy was recommended.

Results obtained after a median follow up period of 48 months were: $81 \%$ complete remission, $9 \%$ partial remission, and $10 \%$ non-responders.

Of the 12 non-responders, two have died of their lymphoma, and nine have been operated on. The work up of the surgical specimens revealed one T cell lymphoma, five secondary high grade lymphomas, and three low grade lymphomas. Two patients received chemotherapy.

Of the 11 patients with partial remission after $H$ pylori eradication, one has since died of a stroke, six have been operated on, two received chemotherapy, and the remaining two have stable disease with no progression, and are still under surveillance only.

On the basis of the endoscopic appearance it is not possible to predict whether $H$ pylori eradication will result in remission of the lymphoma. Nor does the diameter of the tumour provide any clues as to its remission behaviour. The patient with the largest MALT lymphoma having a diameter of $10 \mathrm{~cm}$, has now been in complete remission for seven years since $H$ pylori eradication.

This is in contrast to the depth of infiltration: only in the case of early lymphomas with infiltration of the mucosa and submucosa can complete remission be expected in a high percentage of patients. That is why endoscopic ultrasonography is of great importance in pretreatment staging. We have never seen complete remission of lymphomas infiltrating the muscularis propria and serosa. ${ }^{48}$ However, a single study has also reported complete remission of deeply infiltrating lymphomas. ${ }^{49}$

A good marker for the prognosis of lymphoma remission following $H$ pylori eradication appears to be the determination of $t(11 ; 18)$. While all patients lacking any evidence of this translocation after $H$ pylori eradication showed complete remission, $75 \%$ of those in whom $t(11 ; 18)$ was detected had no remission..$^{51}$ 
Table 1 Results of treatment of gastric MALT lymphoma with $H$ pylori eradication

\begin{tabular}{|c|c|c|c|c|}
\hline First author & Reference & Year & $\begin{array}{l}\text { Number of } \\
\text { patients }\end{array}$ & $\begin{array}{l}\text { Complete } \\
\text { remission (\%) }\end{array}$ \\
\hline Stolte & Not published & 1992 & 10 & 60 \\
\hline Wotherspoon & 42 & 1993 & 6 & 83 \\
\hline Bayerdörffer & 44 & 1995 & 33 & 69 \\
\hline Savio & 56 & 1995 & 12 & 92 \\
\hline Roggero & 57 & 1995 & 26 & 60 \\
\hline Fischbach & 58 & 1996 & 15 & 93 \\
\hline Montalban & 59 & 1997 & 9 & 89 \\
\hline Pinotti* & 60 & 1997 & 49 & 67 \\
\hline Neubauert & 45 & 1997 & 50 & 80 \\
\hline Nobre-Leitao & 61 & 1998 & 17 & 100 \\
\hline Steinbach & 49 & 1999 & 28 & 50 \\
\hline Kato & 62 & 1999 & 19 & 84 \\
\hline Nakamura & 63 & 1999 & 37 & 35 \\
\hline Suzuki & 64 & 1999 & 16 & 88 \\
\hline Oda & 65 & 1999 & 30 & 50 \\
\hline Yamashita & 66 & 1999 & 25 & 64 \\
\hline Suekane & 67 & 1999 & 22 & 68 \\
\hline Thiede $†$ & 68 & 2000 & 84 & 81 \\
\hline Dragosics & Pers. comm. & 2000 & 19 & 84 \\
\hline Fischbach & Pers. comm. & 2000 & 83 & 62 \\
\hline Fischbach & 69 & 2000 & 36 & 89 \\
\hline Ruskoné-Formestaux & 70 & 2001 & 34 & 56 \\
\hline Own results $†$ & & 2001 & 120 & 81 \\
\hline
\end{tabular}

Histological diagnosis of complete remission in biopsy material remains a big problem. The histological examination of 15 surgical specimens of non-responders and of patients with partial remission showed the uncertainty of a biopsy based diagnosis of regression: in cases with regression of the lymphoma in the plane of the mucosa, we found residual lymphoma in the deeper layers of the gastric wall. Even when areas of lymphomas are found in the mucosa in the surgical specimen, the histological diagnosis of lymphoma may nevertheless remain uncertain; in all 15 surgical specimens we failed to detect the most important criterion for the diagnosis of MALT lymphoma-lymphoepithelial lesions-following $H$ pylori eradication.

The polymerase chain reaction (PCR) performed on the VDJ rearrangement of the immunoglobulin heavy chain is unable to help us out of this dilemma. At the primary lymphoma diagnosis prior to treatment, PCR was positive in only $71 \%$ of cases. On the other hand, PCR remained positive in $45 \%$ of the patients with endoscopic, endosonographic, and histological complete remission. ${ }^{52}$

Similar results have been reported by other authors. ${ }^{53}{ }^{54}$ In order to find the source of the monoclonal B cells we carried out PCR studies following microdissection of superficial areas and basal lymphatic aggregates in the mucosa. It was found that the source of the monoclonal B cells is located mainly in the basal lymphatic aggregates. ${ }^{52}$ Future examination of these patients will have to show whether these monoclonal cells can lead to a recurrence, and whether this can occur only after $H$ pylori reinfection, or also in $H$ pylori negative patients.

Of our 97 patients with complete remission of the lymphoma, four have since died. The causes of death were myocardial infarction, stroke, and arterial embolism. So far we have diagnosed nine recurrences, including one high grade lymphoma in the nose, and eight low grade recurrent lesions, one following reinfection with $H$ pylori, in which $H$ pylori eradication therapy again resulted in complete remission of the lymphoma. One patient underwent surgery and one received radiotherapy. In the other five patients, endoscopic appearance remained normal; subsequent histological examinations failed to reveal any lymphoma.

Results of further follow up examinations will have to determine whether the histological finding at a tiny lymphoma focus and/or positive PCR following complete remission of lymphoma has any significance at all, whether any of these cases can be classified as "stable disease" in a "dormant phase" $\mathrm{e}^{\text {"55 }}$ or whether these cells may still give rise to a recurrence.

In three patients with complete remission of the lymphoma we diagnosed early gastric cancer 4-6 years after $H$ pylori eradication. All three cancers were limited to the mucosa, had a diameter of $4-5 \mathrm{~mm}$, and were treated successfully by endoscopic mucosa resection.

\section{Results from other studies}

On reviewing the literature and summarising the results of treatment of gastric MALT lymphoma in different stages with $H$ pylori eradication ${ }^{42} 4445496-70$ we found complete remission rates of between $35 \%$ and $100 \%$ (see table 1 ).

Lymphomas arising in $H$ heilmannii gastritis can also be cured by eradication therapy. ${ }^{71}$ Even in individual cases of high grade MALT lymphoma, $H$ pylori eradication can lead to complete remission of the tumour. ${ }^{72-77} \mathrm{H}$ pylori eradication has even resulted in regression of lymphoma located elsewhere than in the stomach. This has been reported for cases showing regression of a salivary gland lymphoma, ${ }^{78}$ a duodenal lymphoma, ${ }^{79}$ an IPSID lymphoma, ${ }^{80}$ and a rectal lymphoma. ${ }^{81}$

\section{CONCLUSION}

Our study and results reported in the literature confirm that $H$ pylori and $H$ heilmannii gastritis is a pre-MALT lymphoma condition, and that Helicobacter eradication therapy can lead to complete remission in about $80 \%$ of cases of low grade lymphoma, but that some $5 \%$ recurrences per year can occur. Even in individual cases of high grade MALT lymphoma and lymphomas of the duodenum, small intestine, rectum and salivary glands Helicobacter eradication can lead to complete remission of the tumour.

It should, however, be noted that the diagnosis of complete remission is uncertain, and that despite endoscopically, endosonographically, and histologically diagnosed complete remission, monoclonal $\mathrm{B}$ cells are still detected in the gastric mucosa of $45 \%$ of these patients. Further follow up investigations will need to show the significance of this B cell monoclonality. Also in need of clarification is the question whether further regression of these monoclonal cells over the 
course of time is to be expected, whether we are dealing with a non-proliferative, stable disease in a dormant phase, or there is a danger of relapse.

Until these questions have been answered, and as long as no long term results covering follow up periods of more than five years are available, Helicobacter eradication as sole treatment of MALT lymphomas remain experimental, and should be limited to studies in which regular endoscopic-bioptic follow up examinations can be performed.

Nevertheless, the present results already provide support for the title of the review by Peter Isaacson: "Gastric MALT lymphoma: from concept to cure" ${ }^{82}$

\section{SUMMARY}

Over the past 20 years, enormous advances have been made in the field of MALT lymphomas of the stomach. Until the beginning of the 1980s, this lymphoma was diagnosed almost only in an advanced stage and, for the most part, as a highly malignant lesion. It was only after publication of the MALT lymphoma concept by Isaacson in the year 1983 that it became possible to diagnose early stages of this lymphoma.

Our current knowledge of the relation between $H$ pylori infection and MALT lymphomas was initiated by the discovery that mucosa associated lymphatic tissue (MALT) of the stomach is always a consequence of an $H$ pylori infection.

On the basis of these discoveries, the hypothesis was developed that the differential diagnosis of MALT lymphoma and reactive lymphatic infiltrates in biopsy material could be improved by eradicating $H$ pylori. This hypothesis stated that the reactive infiltrate should disappear after $H$ pylori eradication, but the lymphoma infiltrates should persist. However, the investigations based on these considerations showed that early stage, low grade MALT lymphoma with infiltration of the mucosa and submucosa also healed after $H$ pylori eradication therapy.

This prompted us, in 1994, to initiate a study on the treatment of low grade MALT lymphomas by $H$ pylori eradication alone. After reaching a total of 120 patients, we terminated this study. The result was $81 \%$ complete remission, $9 \%$ partial remission, and $10 \%$ non-responders. Comparable studies performed in Europe and Japan produced similar results (complete remission rates of between 35\% and 93\%).

Analysis of our own cases revealed that the endoscopic findings could not be used to derive a prognosis for remission following $H$ pylori eradication. Of greater importance is the depth of penetration of the lymphoma. Only for lymphomas infiltrating mucosa and submucosa, but not for those infiltrating deeper layers of the wall, were we able to achieve complete remission.

PCR for the diagnosis and follow up of remission is not reliable: at primary diagnosis it shows monoclonality in $71 \%$ of the lymphomas, but also in $45 \%$ of cases with complete remission. The source of this monoclonality is persistent basal lymphocytic aggregates. In nine of our patients with complete remission, recurrence of lymphoma was found: high grade lymphoma of the nasal mucosa in one, and local recurrence in eight. These latter were, however, diagnosed only on the basis of histological work up, endoscopic appearance being normal. The question whether these recurrences were perhaps merely a non-proliferative "dormant phase" of monoclonal B cells remains to be answered. Case reports published in recent years have shown that high grade lymphomas can also undergo complete remission following $H$ pylori eradication treatment.

\section{Authors' affiliations}

M Stolte, Institut für Pathologie, Klinikum Bayreuth, 95445 Bayreuth, Germany

E Bayerdörffer, A Morgner, C Thiede, Medizinische Klinik I, Universitätskliniken Dresden, 01307 Dresden, Germany

B Alpen, T Wündisch, A Neubauer, Abtlg. Hämatologie, Onkologie, Immunologie, Philipps Universität Marburg, 35023 Marburg, Germany

\section{REFERENCES}

1 Palmer E. The sarcoma of the stomach. Am J Dig Dis 1950;17:186-95.

2 Isaacson PG, Wright DH. Malignant lymphoma of mucosa-associated lymphoid tissue: a distinctive type of B cell lymphoma. Cancer 1983;52:1410-16

3 Warren JR, Marshall BJ. Unidentified curved bacilli on gastric epithelium in active chronic gastritis. Lancet 1983;330:1273-5.

4 Murayama $\mathbf{H}$, Kikuchi $M$, Eimoto $\mathrm{T}$, et al. Early lymphoma coexisting with reactive lymphoid hyperplasia of the stomach. Acta Pathol Jpn 1984;34:679-86.

5 Radaszkiewicz T, Dragosics B, Baver P. Gastrointestinal malignant lymphomas of the mucosa-associated lymphoid tissue: factors relevant to prognosis. Gastroenterology 1992;102:1628-38.

6 Mohri N. Primary gastric non-Hodgkin's lymphomas in Japan. Virch Arch A 1987:411:295-8.

7 Stolte $M$, Eidt S. The diagnosis of early gastric lymphoma. Z Gastroenterol 1991;29:6-10.

8 Weismüller J, Seifert E, Goronzy R, Stolte M. Das maligne Lymphom des Magens-Fortschritte in der Frühdiagnostik. Schweiz Rundschau Med (Praxis) 1986;75:1531-2.

9 Eidt $S$, Stolte $M$. Evidence of a malignant cycle in early gastric lymphoma. Endoscopy 1994;26:295-8

10 Eidt S, Stolte M, Fischer R. Helicobacter pylori gastritis and gastric non-Hodgkin's lymphoma. J Clin Pathol 1994:47:436-9.

11 Dragosics B, Baver P, Radaszkiewicz T. Primary gastrointestinal non-Hodgkin's lymphomas. A retrospective clinicopathological study of 150 cases. Cancer 1985;55:1060-73

12 Cogliatti SB, Schmid U, Schumacher U, et al. Primary B-cell gastric lymphoma: a clinicopathological study of 145 patients. Gastroenterology 1991;101:1159-70.

13 Isaacson PG, Spencer J. Wright DH. Classifying primary gut lymphomas. Lancet 1988;2:1148-9.

14 Harris NL, Jaffe ES, Stein H, et al. A revised European-American classification of lymphoid neoplasms. A proposal from the international lymphoma study group. Blood 1994:84:1361-92.

15 Hamilton SR, Aaltonen LA, eds. Tumours of the digestive system. World Health Organization classification of tumours. Lyon: ARCPress, 2000.

16 Isaacson PG, Spencer J. Malignant lymphoma of mucosa-associated lymphoid tissue. Histopathology 1987;11:445-62

17 Isaacson PG, Norton AJ. Extranodal lymphomas. Edingburgh: Churchill Livingstone, 1994

18 De Jong $\mathbf{D}$, Boot J, van Heerde $\mathrm{P}$, et al. Histological grading in gastric lymphoma: pretreatment criteria and clinical relevance. Gastroenterology 1997; 112:1466-74.

19 Wyatt JI, Rathbone BJ. Immune response of the gastric mucosa to Campylobacter pylori. Scand J Gastroenterol 1988;23(suppl 142):44-9.

20 Stolte M, Eidt S. Lymphoid follicles in the antral mucosa: immune response to Campylobacter pylori. J Clin Pathol 1989;42:1269-71.

21 Doglioni C, Wotherspoon AC, Moschinie A, et al. High incidence of primary gastric lymphoma in northeastern ltaly. Lancet 1992;339:1175-6.

22 Wotherspoon AC, Ortiz-Hidalgo C, Falzon MR, et al. Helicobacter pylori-associated gastritis and primary B-cell gastric lymphoma. Lancet 1991;338: $1175-6$.

23 Parsonnet J, Hansen S, Rodriguez L, et al. Helicobacter pylori infection and gastric lymphoma. N Engl J Med 1994;330:1267-71.

24 Enno A, O'Rourke J, Lee A, et al. MALToma-like lesions in the stomach resulting from long-standing Helicobacter infection in the mouse. Am J Gastroenterol 1994;89:1357.

25 Enno A, O'Rourke J, Howlett CR, et al. MALToma-like lesions in the murine gastric mucosa after long-term infection with Helicobacter felis: a mouse model of Helicobacter pylori gastric lymphoma. Am J Pathol 1995; 147:217-22.

26 Enno A, O'Rourke J, Howlett CR, et al. Mouse to mouse resuscitation of low-grade MALT lymhoma induced by prolonged Helicobacter infection. A preliminary study of transplanted tumors. Gastroenterology 1996;1 10:A536.

27 Enno A, O'Rourke J, Braye S, et al. Antigen-dependent progression of mucosa-associated lymphoid tissue (MALT)-type lymphoma in the stomach. Effects of antimicrobial therapy on gastric MALT lymphoma in mice. Am J Pathol 1998;152:1625-32.

28 O'Rourke JL, Enno A, Dixon MF, et al. Gastric B-cell lymhomas induced in the single mouse strain by various isolates of Helicobacter heilmannii. Similarities and differences. Gut 1995;37(suppl 1):A7.

29 Stolte $\mathbf{M}$, Wellens $E$, Bethke B, et al. Helicobacter heilmannii (formerly Gastrospirillum hominis) gastritis: an infection transmitted by animals? Scand J Gastroenterol 1994;29:1061-4.

30 Meining A, Stolte $M$, Hatz R, et al. Differing degree and distribution of gastritis in Helicobacter pylori-associated diseases. Virchows Arch 1997:431:11-15.

31 Trebesius K, Adler K, Vieth M, et al. Specific detection and prevalence of Helicobacter heilmannii-like organisms in the human gastric mucosa by fluorescent in situ hybridization and partial 16S ribosomal DNA sequencing. J Clin Microbiol 2001;39:1510-16.

32 Qin Y, Greiner A, Trunk MF, et al. Somatic hypermutation in low-grade mucosa-associated lymphoid tissue-type B-cell lymphoma. Blood 1995;86:3528-34

33 Du $M$, Peng $H$, Singh $N$, et al. The accumulation of p53 abnormalities is associated with progression of mucosa-associated lymphoid tissue lymphoma. Blood 1992;339:745-7.

34 Hoeve MA, Gisbertz IAM, Schoutten HC, et al. Gastric low-grade MALT lymphoma, high-grade MÁLT lymphoma and diffuse large B cell 
lymphoma show different frequencies of trisomy. Leukemia 1999; 13:799-807.

35 Ott G, Katzenberger T, Greiner A, et al. The $t(11 ; 18)(q 21 ; q 21)$ chromosome translocation is a frequent and specific aberration in low-grade but not high-grade malignant non-Hodgkin's lymphoma of the mucosa-associated lymphoid tissue (MALT)-type. Cancer Res mucosa-associated $1997 ; 57: 3944-8$.

36 Agaki T, Motegi $M$, Tamura A, et al. A novel gene, MALT1 at 18q21, is involved in $1(1,18)(q 21 ; q 21)$ found in low-grade B-cell lymphoma of mucosa-associated lymphoid tissue. Oncogene 1999:18:5785-94.

37 Dierlamm J, Baens M, Wlodarska I, et al. The apoptosis inhibitor gene AP12 and a novel $18 q$ gene, MLT, are recurrently rearranged in the $t(11 ; 18)(q 21 ; q 21)$ associated with mucosa-associated lymphoid tissue lymphoma. Blood 1999:93:3601-9.

38 Ohashi S, Sgawa K, Okamura S, et al. A clinicopathologic study of gastric mucosa-associated lymphoid tissue lymphoma. Cancer 2000;88:2210-19.

39 Fa YS, Rizkalla K, Engel J. Interstitial deletion of $8(q 23 ; q 21)$ in diffuse large B-cell gastric lymphoma. Cancer Genet Cytogenet 1999:115:28-31.

40 Ferreri AJ, Cordio S, Paro S, et al. Therapeutic management of stage I-II high-grade primary gastric lymphomas. Oncology 1999;56:274-82.

41 Stolte M. Helicobacter pylori and MALT-lymphoma. Lancet 1992:339:745-7.

42 Wotherspoon AC, Doglioni C, Diss TC, et al. Regression of primary low-grade B-cell gastric lymphoma of mucosa-associated lymphoid type after eradication of Helicobacter pylori. Lancet 1993;342:575-7.

43 Hussell T, Isaacson PG, Crabtree JE, Spencer J. The response of cells from low-grade B-cell gastric lymphoma of mucosa-associated lymphoid tissue to Helicobacter pylori. Lancet 1993;342:571-4.

44 Bayerdörffer E, Neubauer A, Rudolph B, et al. MALT lymphoma study group. Regression of primary gastric lymphoma of mucosa-associated tissue type after cure of Helicobacter pylori infection. Lancet 1995;345:1591-4

45 Neubauer A, Thiede C, Morgner A, et al. Cure of Helicobacter pylori infection and duration of remission of low-grade gastric mucosa-associated lymphoid tissue lymphoma. J Natl Cancer Inst 1997;89:1350-5.

46 Morgner A, Bayerdörffer E, Neubaver A, et al. Gastric MALT lymphoma and its relationship to Helicobacter pylori infection: management and pathogenesis of the disease. Micros Res Tech 2000;48:349-56.

47 Isaacson PG, Norton AJ. Extranodal lymphomas. Edinburgh: Churchill Livingstone, 1994.

48 Sackmann M, Morgner A, Rudolph B, et al. Regression of gastric MALT lymphoma after eradication of Helicobacter pylori is predicted by endosonographic staging. MALT Lymphoma Study Group. Gastroenterology 1997; 113:1087-90

49 Steinbach G, Ford R, Glober G, et al. Antibiotic treatment of gastric lymphoma of mucosa-associated lymphoid tissue. Ann Intern Med 1999:131:88-95

50 Alpen B, Neubauer A, Dirlamm J, et al. Translocation $f(11 ; 18)$ absent in early gastric marginal zone B-cell lymphoma of MALT type responding to eradication of Helicobacter pylori infection. Blood 2000;95:4012-15.

51 Liu H, Ruskone-Formeshaux A, Lavergue-Slove A, et al. Resistance of $\mathrm{t}$ $(11 ; 18)$ positive gastric mucosa-associated lymphoid tissue lymphoma to Helicobacter pylori-eradication therapy. Lancet 2001;357:39-40

52 Thiede C, Wündisch T, Alpen B, et al. Long-term persistence of monoclonal B cells after cure of Helicobacter pylori infection and complete histologic remission in gastric mucosa-associated lymphoid tissue B-cell lymphoma. J Clin Oncol 2001:19:1600-9.

53 Savio A, Franzin G, Wotherspoon AC, et al. Diagnosis and posttreatment follow-up of Helicobacter pylori positive gastric lymphoma of mucosa-associated lymphoid tissue: histology, polymerase chain reaction, or both? Blood 1996:87:1255-60.

54 Aiello A, Giardini R, Tondini C, et al. PCR-based clonality analysis: a reliable method for the diagnosis and follow-up monitoring of conservatively treated gastric B-cell MALT lymphomas? Histopathology 1999;34:326-30.

55 Isaacson PG, Diss TC, Wotherspoon AC, et al. Long-term follow-up of gastric MALT lymphoma treated by eradication of $\mathrm{H}$ pylori with antibiotics. Gastroenterology 1999;117:750-1.

56 Savio A, Franzin G, Wotherspoon AC, et al. Diagnosis and posttreatment follow-up of Helicobacter pylori-positive gastric lymphoma of mucosa-associated lymphoid tissue; histology, polymerase chain reaction, or both? Blood 1996;87: 1255-60.

57 Roggero E, Zucca E, Pinotti G, et al. Eradication of Helicobacter pylori infection in primary low-grade gastric lymphoma of mucosa-associated lymphoid tissue. Ann Intern Med 1995;122:767-79.
58 Fischbach W, Kolve ME, Engemann R, et al. Unexpected success of Helicobacter pylori eradication in low-grade lymphoma. Gastroenterology 1996;110:A512.

59 Montalban C, Manzanal A, Boixeda D, et al. Helicobacter pylori eradication for the treatment of low-grade gastric MALT lymphoma: follow-up together with sequential molecular studies. Ann Oncol 1997; 8(suppl 2).

60 Pinotti G, Zucca E, Roggero E, et al. Clinical features, treatment and outcome in a series of 93 patients with low-grade gastric MALT lymphoma. Leuk Lymphoma 1997;26:527-37.

61 Nobre-Leitao C, Lage P, Cravo M, et al. Treatment of gastric MALT lymphoma by Helicobacter pylori eradication: a study controlled by endoscopic ultrasonography: Am J Gastroenterol 1998;93:732-6.

62 Kato T, et al. Regression of gastric low-grade MALT lymphoma after eradication of Helicobacter pylori. Stomach Intest 1999;34:1345-52.

63 Nakamura T, et al. The changes of the endoscopic, roentgenographic and pathological findings of gastric MALT lymphoma after cure of $\mathrm{H}$. pylori infection. Stomach Intest 1999;34:1353-66.

64 Suzuki T, et al. Clinicopathological features of MALT lymphoma. Stomach Intest 1999;34:1367-79.

65 Oda I, et al. Endoscopic evaluation of Helicobacter pylori eradication. Stomach Intest 1999;34:1381-8.

66 Yamashita H, et al. Histological features of low-grade MALT lymphoma showing complete regression after Helicobacter pylori eradication and prediction time of its effectivenes - the value of clinical typing based on endosonographic findings. Stomach Intest 1999;34:1389-96.

67 Suekane $\mathrm{H}$, et al. Clinical course and practical guideline after eradication of Helicobacter pylori-the value of clinical typing based on endosonographic findings. Stomach Intest 1999:34:1397-409.

68 Thiede C, Wündisch T, Neubauer B, et al. Eradication of Helicobacter pylori and stability of emissions in low-grade gastric B-cell lymphomas of the mucosa-associated lymphoid tissue: results of an ongoing multicenter trial. Cancer Res 2000;156:125-33.

69 Fischbach W, Dragosics B, Kolve-Goebeler ME, et al. Primary gastric B-cell lymphoma: results of a prospective multicenter study. Gastroenterology 2000;119:1191-202.

70 Ruskoné-Fourmestaux A, Lavergne A, Aegerter PH, et al. Predictive factors for regression of gastric MALT lymphoma after anti-Helicobacter pylori treatment. Gut 2001;48:297-303.

71 Morgner A, Lehn N, Andersen LP, et al. Helicobacter heilmannii-associated primary gastric low-grade MALT lymphoma: complete remission after curing the infection. Gastroenterology 2000;118:821-8

$72 \mathrm{Ng}$ WW, Lam CP, Chau WK, et al. Regression of high-grade gastric mucosa associated lymphoid tissue lymphoma with Helicobacter pylori after triple antibiotic therapy. Gastrointest Endosc 2000;51:93-6.

73 Morgner A, Miehlke S, Fischbach W, et al. Complete remission of primary high-grade B-cell gastric lymphoma after cure of Helicobacter pylori infection. J Clin Oncol 2001;19:2041-8.

74 Falco-Jover G, Martinez-Egea A, Sanchez CJ, et al. Regression of primary gastric B-cell mucosa-associated lymphoid tissue (MALT) lymphoma after eradication of Helicobacter pylori. Rev Esp Enferm Dig 1999;91:541-8.

75 Seymour JF, Anderson RP, Thathal PS. Regression of gastric lymphoma with therapy of Helicobacter pylori infection. Ann Intern Med 1997; 127:247.

76 Chen LT, Cheng AL, Shyu Ly, et al. Anti-Helicobacter pylori therapy in high-grade mucosa-associated lymphoid tissue lymphoma of the stomach. Proc Am Soc Clin Oncol 1998;17:289A.

77 Roggero E, Copie-Bergman C, Traulle C, et al. Regression of high-grade B-cell gastric lymphoma after eradication of Helicobacter pylori infection. Ann Oncol 1999;10:67.

78 Alkan S, Karcher DS, Newman MA, Cohen P. Regression of salivary gland MALT lymphoma after treatment for Helicobacter pylori. Lancet 1996;348:269

79 Nagashima R, Takeda H, Maeda K, et al. Regression of duodenal mucosa-associated lymphoid tissue lymphoma after eradication of Helicobacter pylori. Gastroenterology 1996;111:1674-8.

80 Fischbach W, Tacke W, Greiner A, et al. Regression of immunoproliferative small intestinal disease after eradication of Helicobacter pylori. Lancet 1997;349:31-2.

81 Matsumoto T, Lida M, Shimizu M. Regression of mucosa-associated lymphoid tissue lymphoma of rectum after eradication of Helicobacter pylori. Lancet 1997;350:115-16.

82 Isaacson PG. Gastric MALT lymphoma: from concept to cure. Ann Oncol 1999;10:637-45. 